\title{
The Fiscal Pressure Endured by Trading Companies
}

\author{
Constantin Cucoşel \\ Technical University of Cluj-Napoca - the Northern Academic Center of Baia Mare \\ "Vasile Goldis" West University of Arad -Baia Mare subsidiary \\ E-mail: cucoselc@yahoo.com
}

Accepted: Feb 16, 2013 Published: March 03, 2013

Doi:10.5296/ijhrs.v3i1.3350 URL: http://dx.doi.org/10.5296/ijhrs.v3i1.3350

\begin{abstract}
:
In order to carry out the extremely complex and diverse tasks it has to perform, the state needs important financial resources it can obtain either from within the country, from its taxpayers, physical persons or legal entities, or from external sources when internal resources are insufficient.

The society cannot exist in the absence of the duties and taxes whose necessity is, on one hand stipulated by the Constitution, and on the other, proved by historical reality. It is only logical for these taxes to be imposed to the taxpayers. Fiscal pressure is a concept closely related to the notion of taxation and is often used to describe its level.
\end{abstract}

Keywords: Taxes, Fees, Taxation, Fiscal Pressure, Tax Evasion

\section{Introduction}

In order to satisfy social welfare requirements, the institutions that deal with these aspects need to use public financial resources and covering such expenses requires the existence of equal sources of income. Since these institutions do not provide any paid services, their expenses can only be covered using the resources collected by public authorities in the form of taxes, fees or contributions, and if such resources turn out to be insufficient, they obtain additional financing by contracting loans..

There are several different approaches in defining taxation, one of them stating that taxation stands as the whole of taxes, dues and contributions in a given state.

Another approach places a special emphasis on the elements that define taxation in general, defining it in terms of the relationships existing between its elements. Thus, in keeping with this approach to taxation, some authors believe that the taxation system includes the whole of concepts, principles, methods, processes related to several elements (taxable matter, tax rates, tax subjects) connected through relationships arising from the design, legal regulation, set up and collection of taxes and managed in keeping with fiscal legislation, in order to achieve the aims of the system.

Depending on the approach used (whether from a juridical, economic or social 
point of view), taxation is assigned one or several characteristics and meanings, as follows (Beju, Cucosel, 2010):

- taxation is a concept related to the state and public finances;

- it is a feature of state policy with regards to taxes and duties;

- it is an attribute of a sovereign state, but the state must also take into account the wishes and agreement of tax-payers in that which concerns taxes;

- it stands as the whole of regulations and operations involved in establishing and collecting taxes and duties;

- it is an expression of the fiscal burdens endured by physical and legal persons.

\section{Aspects of fiscal pressure: content, forms of expression}

Taxes represent mainly a source of income for public resources; the weight of taxes in the total amount of public revenues exceeds $80 \%$, verging on $90 \%$, given that revenues of a non-fiscal nature are objectively low, which is due particularly to the low participation of the public sector to economic activities and to the low degree of self-financing existing for the activities carried out by public institutions.

Professionals often speak of increasing or relaxing taxation. This obviously refers to an increase or decrease of the tax rates, which means a change in fiscal pressure.

Whether it's called fiscal burden, fiscal pressure, tax ratio, or rate of compulsory contributions, the main point is that it involves an obligation towards the state which results in a decrease of private revenues.

The taxation level can't be measured based on the absolute amount of taxes collected, even when following its progress in time. The amount of taxes may suffer changes even without the state changing its expectations from the tax-payers, which means that fiscal pressure remains the same. The main factors that influence this amount are the number of tax-payers, the taxable materials they own, and the inflation rate.

What this means is that the taxation level or fiscal pressure refers to how burdensome the taxes are, that is how difficult to bear are taxes for the tax-payers . (Tulai, 2003).

The means to measure fiscal pressure is by calculating the rate of taxation, which represents "a measuring value that indicates the percentage of revenues extracted from production, which become part of the budget through a process of compulsory and public appropriation, instead of being made freely available to private economic initiatives", as defined by Gheorghe Manolescu. Or, according to other authors, fiscal pressure or fiscal burden is an economic reflection of the value redistribution processes that allow part of the revenue created by the actual economy to escape the mechanisms of the market and, instead, be taken over by the state. The part taken over from the revenue achieved, accumulated, consumed, by means of tax levying, takes the form of tax flows, the source of which are the entities active within the actual economy, whereas the destination is the public economy. This part, which constitutes duties levied on individual or global revenues to contribute to tax flows, is the essence of the concept of fiscal pressure, used in order to measure the level of 
compulsory contributions within a given tax system.(Corduneanu, 1998).

\section{Indicators used for measuring fiscal pressure}

The basic source for the taxes and duties collected to be made available to the state consists of the gross domestic product (GDP) and the national wealth. The nominal rates of taxes and duties depend on the government's tax policy, as well as on inflationist processes.

To obtain a more accurate measurement of the level of taxation, one must accept the concept of calculating the size of fiscal obligations relative to the sources they are covered from.

Fiscal pressure as level of compulsory contributions is generally indicated by the rate of taxation. This rate may be calculated at a national (global) level, at the level of the business unit (company), or at individual level (in the case of tax-payers who are physical persons). The rates of fiscal pressure may also be calculated for various organisational levels:

- for a certain field - industry, agriculture, tourism, etc.;

- for a given local community.

In either case, this rate constitutes a percentage ratio between the total amount of compulsory contributions to the state (taxes, duties and other compulsory contributions), on the one hand, and, on the other hand, the GDP, the turnover (economic value added or share capital) or individual revenues, depending on the level for which the rate is calculated. The rates may differ depending on the structure of the compulsory contributions taken into account.

Fiscal pressure stricto sensu (the rate of taxation strictly speaking) is calculated by taking into account only tax contributions to the state budget (to both the central budget and local budgets) for a given interval (usually one year).

Taxes collected over a given interval

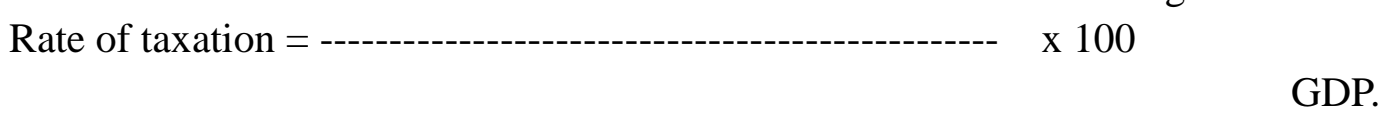

This rate, however, does not reflect the whole of obligations towards the state and the entire revenue that is taken over by the state. This method for evaluating fiscal pressure has the drawback of sub-evaluating tax burdens, in particular in the case of a tax system where most duties are indirect taxes (excise duties, value added tax, customs taxes), as they are included in the prices of the products that the size of the GDP depends on, increasing it artificially and lowering the rate of taxation. (Beju, Cucoşel, 2010).

In the recent years both the number and amount of certain social contributions has increased, so that it is now necessary and useful to calculate a more global indicator, which is the global fiscal pressure, which is established taking into account, in addition to the duties and taxes owed to the central budget and the local budgets, also the so-called social contributions, even though they are managed through separate budgets, still under the 
jurisdiction of the state, and such contributions are as compulsory as the rest of the taxes. In fact, in some countries these contributions are included in the actual tax system, in which case social insurance and social welfare are financed through the state budget.

Taxes collected + social

contributions

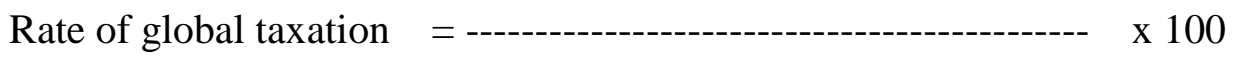

GDP.

The list of compulsory payments also includes (at least for the time being) the numerous contributions to other special funds, which are managed by the state through distinct budgets but approved annually through the law on the state budget. To obtain a genuine picture of global fiscal pressure, one must also take into account these contributions to special funds, whenever the introduction of such a contribution is not followed immediately by a decrease in the amounts of other duties to the state budget, and that has usually been the rule in Romania. This category includes not only the funds of social insurance and social welfare, but also the other special appropriation funds that are being administered by the state, supplied with money from compulsory contributions imposed upon physical and/or legal persons and generated by the systematic attempts at decreasing the expenses from the state budget which were carried out in Romania after 1989. All these taken together, along with the duties and taxes collected to the state budget and local budgets, amount to what is known as compulsory payments. (Tulai, 2003).

Taxation practices also involve other indirect indicators used for measuring fiscal pressure. One example is the rate of expanded taxation, obtained by also taking into account other sources for financing public expenses, beside compulsory payments. Some believe that, whenever one is making such calculations, one should also add to the compulsory payments the entire budget deficit, financed through the state's indebtedness, as the loans contracted by the state are actually delayed taxes or, more accurately, taxes collected in advance.

There are also some opinions that claim that the various models for calculating the rate at a national level only reflect the first aspect of taxation and fail to accurately represent the second aspect, which refers to how certain public requirements are satisfied through the expenses made by the state from the taxes collected. This issue can be solved by calculating the rate of net taxation, which is obtained by eliminating from the compulsory payments the part spent by the state for the benefit of the tax-payers (in the form of social services or other types of services provided to families or individuals) and the subsidies granted to business units. So this version only takes into account the compulsory payments necessary to the public administration for its own functioning, excluding all the elements that merely pass through the public treasury (transfers, subsidies or allowances). Thus, the rate of net taxation takes into account the reversibility of taxes and the existence of the negative taxation. 
In the case of another indirect indicator used for measuring fiscal pressure, specifically the rate of consolidated taxation, what the model eliminates are the redundant payments. The first level of consolidation consists of eliminating the social contributions and taxes paid by public administration bodies, whereas at the next level it is obtained by eliminating all self-financed compulsory payments (not only those that are covered by public administration bodies, but also those that are covered from the revenues provided by public administration bodies). For instance, salary tax constitutes a source of revenue to the state budget, but some of that revenue is redistributed to local budgets.

Fiscal pressure at a national level is determined by the requirements entailed by financing public expenses. However, there is also a psychological fiscal pressure that tax-payers feel, an indicator that measures the tolerance threshold for taxation, which is the individual fiscal pressure, calculated as the ratio between the total amount of compulsory payments made by a given tax-payer and the total amount of revenues obtained by the same tax-payer before taxation; this differs from one tax-payer to the next due to the differences in the applicable fiscal treatment and to the customization of taxes according to economic or social criteria.

Thus, the individual fiscal pressure measures the sacrifice that the tax-payer must make by paying taxes to the state, but it doesn't accurately reflect the size of the tax burden, which must be determined in accordance with the level of fulfilment of the subsistence needs and of the ability to save money from the revenues remaining after tax. That is why pro-rata taxation is not as fair as progressive taxation, since the burden will be felt differently by someone whose remaining net income fails to meets his stringent living requirements if he pays the same tax rates as someone with a considerably larger income, who can still maintain decent living conditions and save money.

The purchasing power of the tax-payer's net income, remaining after the payment of the direct taxes on revenues and wealth, also depends on the level of indirect taxes applicable to the tax-payer when he purchases commodities and services.

To conclude, the actual individual tax burden must be measured taking into account all the direct and indirect taxes that the tax-payer - the natural person - has to pay, even if not all of them are assigned by law as his personal duty. (Tulai, 2003).

At the level of business units, fiscal pressure may be calculated as the ratio between the total amount of taxes and duties paid and the turnover (economic value added) or the share capital. Thus, fiscal pressure stands as a percentage ratio between the compulsory payments to the state that the business unit must make and the economic value added obtained over a given interval, usually of one year.

The fact that taxes and duties weigh so much within the whole of the activities carried out by business units makes them sometimes difficult to bear, which results, on the one hand, in discouraging activities that generate newly created value, and, on the other hand, in attempts to find solutions (both legal and illegal) that would allow such business units to avoid either entirely or in part the payment of their fiscal obligations. Thus, a case can be made for the existence of a certain fiscal pressure at a microeconomic level, where the 


\section{Macrothink

indicator for measuring fiscal pressure is calculated as follows:

$$
\begin{gathered}
\sum(\mathrm{I}+\mathrm{T})-\sum\left(\mathrm{S}_{\mathrm{p}}+\mathrm{T}_{\mathrm{c}}\right) \\
\mathrm{P}_{\mathrm{f}}=\text {----------------------} \mathrm{x} 100,
\end{gathered}
$$

where:

I - taxes paid

$\mathrm{T}$ - duties paid

$\mathrm{S}_{\mathrm{p}}$ - subsidies received

$\mathrm{T}_{\mathrm{c}}$ - consumption taxes

$\mathrm{V}_{\mathrm{a}}$ - value added

$\mathrm{V}_{\mathrm{b}}$ - gross revenues. (Mates and co., 2009).

The structure of compulsory payments often includes corporate tax, contributions to the social insurance and social welfare funds and other direct taxes on wealth payable to the local budget and included in the company's costs.

Naturally, the business units also pay to the budget other taxes, duties and contributions, but they are all covered by the given business unit. The V.A.T., the excise duties and customs duties are not taken into account because the company recovers such amounts from the consumer, who covers them by paying them upon purchase of a product.

The type of tax that does have a direct impact on the business unit is the corporate tax, as profit is for a private company what the salary is for its employee. (Tulai, 2003).

The other payments, such as contributions to the social insurance and social welfare funds, building taxes, land taxes, vehicle taxes, included in the cost of products and recovered through their prices, have an indirect impact, through the level of costs, on the size of the profit, which is why they too are classified as negative financial flows for the business unit. If one adds to all these the other contributions to special funds, beside those of social insurance and social welfare, one may obtain a real image of the fiscal pressure endured by business units.

\section{Conclusions}

A study on the evolution of taxes owed by business units over the interval $2006-2010$ leads to several conclusions, as follows:

- the lump-sum tax, given all the errors in the legislation, was a burdening tax for companies because it had to be paid even if the company had recorded losses over that fiscal year;

- by increasing the rate of the V.A.T., which is a high productivity tax, to $24 \%$, the state efficiently managed to penalize consumption but also, at the same time, to increase the selling price for the products manufactured, which impacted on the company's turnover by decreasing the amounts of products sold; 
- the high level of the social contributions owed by the company may lead to a widely used practice which consists of declaring the revenues obtained as limited to the level of the minimum official salary, so as to avoid the payment of increased contributions; this occurs very often (and may be associated to tax evasion);

- in the case of direct taxes, the level of taxation influences the voluntary compliance behaviour or the tax evasion behaviour, since, from the tax-payer's point of view, the tax is seen as an irrecoverable loss (due to the budgetary principle of non-appropriation of revenues);

- as far as the budget of health insurance was concerned, the law was changed several times - in 2008 alone there were three changes in legislation - not only in that which concerns the rates of the contributions but also with regards to the taxation base, which has been confusing for business units.

In terms of the relationship between tax-payers (companies) and law-makers, certain conclusions may be formulated:

- a viable business environment may only be preserved by maintaining transparent communications; any attempt at improving the relationship between the authorities and the tax-payers must be based on a continuous process of change in the authorities' attitude;

- the flexibility and transparency of such a relationship requires an improved legislative formalisation of the rights and obligations between the parties and the possibility of direct negotiation and intermediation between tax-payers and the fiscal authority;

- the evolution of the legislative framework must cover the current requirements imposed by the economic environment without constituting a factor of uncertainty or destabilisation for the tax-payer.

According to the Fiscal and Budgetary Strategy of the Government for the period between 2012 and 2014, the medium term aims of the fiscal policy with regards to preventing and fighting tax evasion are as follows: (Ministry of Public Finances: Fiscal and Budgetary Strategy for 2012-2014):

- Fighting off multi-national fraud, in particular at the level of the European Union countries;

- Implementing control over e-commerce;

- Implementing a programme of check-ups on very rich individuals;

- Increasing the number of road operations for the mobile teams of the Financial Guard and of the Customs National Authority;

- Monitoring and operative interventions in the fields of high fiscal risk (products that are subject to excise duties, purchases from other countries of the European Union, import/export operations);

- Ensuring that the informatics system of the Financial Guard operates in full cooperation with the informatics systems of other institutions involved in fighting off tax evasion;

- Developing and implementing computer software for monitoring the status of 
products that are normally subject to excise duties but for which excise duties have been suspended, including those that circulate between countries of the European Union and have the excise duties paid in the member state that they are shipped from - EMCS stage 3;

- Improving the monitoring on the movement of excisable products and fiscal warehouses, including in conterminous areas;

- Purchasing specialized systems/equipment for monitoring and ensuring the security of road transportation for commodities, as well as mobile scanning devices, in order to decrease tax evasion and improve fiscal and customs control, for any item where risk analyses require a non-destructive check-up;

- Initiating law proposals meant to amend current legal provisions so as to make it compulsory to impose a new security system for hallmarks and stamps;

- Applying specific measures for customs value control for general commodities, respectively shoes and clothing;

- Selecting declaration for further verification or for re-verification, depending on the following risk factors: tariff classification, origin, customs value, terms and conditions for the customs operations for which a suspension of customs fees was granted;

- Improving the level of cooperation between the computer system of the Financial Guard and the computer systems of other institutions involved in fighting off tax evasion.

\section{BIBLIOGRAPHY :}

Beju, V., 2006, Resursele financiare publice. Evaziunea fiscală şi corupţia, Editura Casa Cărţii de Ştiinţă, Cluj-Napoca

Beju, V., Cucoşel, C., 2010, , Fiscalitate, evaziune şi armonizare fiscală, Editura Universităţii de Nord, Baia Mare

Corduneanu, C., 1998, Sistemul fiscal în ştiinţa finanţelor, Editura Codecs, Bucureşti

Cucoşel, C. 2004, Finanţele publice, Editura Risoprint, Cluj-Napoca

Cucoşel, C. 2001, Fiscalitatea în România. Teorie şi practică, Editura Universităţii de Nord, Baia Mare

Mateş, D. Şi colectiv, 2009, Contabilitatea evenimentelor şi tranzacţiilor între standarde, directive şi reglementări fiscale, Editura Mirton, Timişoara

Tulai, C., 2003, Finanţele publice şi fiscalitatea, Editura Casa Cărţii de Ştiinţă, Cluj-Napoca

*** Legea nr. 571/2003 privind Codul fiscal, publicată în Monitorul Oficial nr. 927 din 23 decembrie 2003, republicată, cu modificările şi completările ulterioare

*** Ordonanţa Guvernului nr. 92/2003 privind Codul de procedură fiscală, republicată în Monitorul Oficial nr. 863 din 26 septembrie 2005, cu modificările şi completările ulterioare

*** Ordonanţa de Urgenţă a Guvernului nr. 117/2010 pentru modificarea şi completarea Legii nr. 571/2003 privind Codul fiscal şi reglementarea unor măsuri financiar-fiscale, publicată în Monitorul Oficial nr. 891 din 30 decembrie 2010

*** Guvernul României - Strategia fiscal bugetară pe perioada 2012-2014

www.mfinante.ro 